\title{
Molecular Characterization of Anguilla from Cibereum and Sapuregel Rivers Segara Anakan Watersheds Cilacap, Central Java
}

\author{
Agus Nuryanto*, Dian Baghawati, Kusbiyanto, Moh Husein Sastranegara, Farida Nur Rachmawati \\ Faculty of Biology, Universitas Jenderal Soedirman \\ Jl. Dr. Soeparno No. 63 Purwokerto, Central Java, Indonesia. 53122 \\ *Email: agus.nuryanto@unsoed.ac.id
}

\begin{abstract}
The taxonomic status of Anguilla species' in river watershed that empties into Segara Anakan Cilacap is uncertain, thereby making it difficult for further studies to be carried out to determine its genetic in that area. Therefore, this study evaluates Anguilla's taxonomic status and population genetic in Cibeureum and Sapuregel River watersheds. Data were obtained from molecular characterization study using cytochrome c oxidase 1, with fourteen Anguilla specimens collected from two sequenced watersheds. Taxonomic status was determined based on homology and divergence values and monophyly of the samples to the reference species. Meanwhile, genetic divergences among samples to the reference species were calculated based on the Juke-Cantor substitution model in DnaSP6. A homology test was performed using a basic local alignment search tool, with monophyly inferred from the cladogram, which was developed using neighbor-joining and maximum likelihood algorithms in MEGAX with 1000 pseudoreplicates and out-group comparison. Furthermore, population genetic was analyzed through polymorphism, haplotype, nucleotide diversity within the population, divergence, and genetic differences. All calculations conducted in Arlequin 3.5 had Anguilla samples comprising of high (99.23\% to 99.84\%) to low genetic divergences $(0.224 \%$ to $1.127 \%)$. The result shows that cladogram with all Anguilla samples formed a monophyletic clade with A. bicolor, separated from their taxa. Furthermore, Anguilla samples from both watersheds have low genetic polymorphisms with medium to high haplotype and nucleotide diversity. The population's comparison proved that both populations have low genetic divergence, and no genetic difference based on variance analysis $(\mathrm{p}=0761)$. Therefore, Anguilla resources in river watersheds that empty into Segara Anakan are a single genetic conservation unit.
\end{abstract}

Keywords: diversity; eel; genetic; population; Segara Anakan

Article History: Received 26 August 2020; Received in revised form 26 September 2020; Accepted 23 November 2020; Available online 30 December 2020

How to Cite This Article: Nuryanto A, Baghawati D, Kusbiyanto K, Sastranegara MH, Rachmawati FN. 2020. Molecular characterization of Anguilla from Cibereum and Sapuregel Rivers Segara Anakan Watersheds Cilacap, Central Java. Biogenesis: Jurnal Ilmiah Biologi. vol 8(2): 145-156. doi: https://doi.org/10.24252/bio.v8i2.15532.

\section{INTRODUCTION}

An eel is a snake-like fish with a slender, elongated body and poorly developed fins, proverbial for its slipperiness, it belongs to the genus Anguilla, and locally known as ikan sidat in Indonesian. It is a catadromous fish, which resides in fresh water and goes to the ocean to spawn (Aoyama, 2009). Anguilla spp. are economically valuable commodities which are frequently exported to Japan. The market demands, particularly for A. bicolor are met based on culture. Its cultivation is primarily supported by naturally collecting Leptocephalus larvae or glass eels (Tanaka et al., 2014), although it leads to overexploitation when excessively carried out (Rachmawati \& Susilo, 2011). In addition, it is also proven by the alteration of its conservation status from Least Concern to Nearly Threatened in 2010, 2017 , and 2020 respectively, as reported by the
IUCN (Jacoby et al., 2014; Pike et al., 2020). According to Jacoby \& Gollock (2014), sequentially, the conservation status of $A$. marmorata and A. nebulosa is Least Concern, and Not Evaluated as stated in the 2013 version of IUCN Red List.

These alterations were based on several reasons, including the natural harvesting of $A$. bicolor (Jacoby et al., 2014). Therefore, conservation plans and actions are urgently needed to ensure its sustainability. Jacoby et al. (2014), reported that it is crucial to carry out taxonomic research on the conversion of $A$. bicolor. This is due to the fact that useful information is only obtained when the taxonomic status is valid (Nuryanto et al., 2019).

Globally, a total of 18 Anguilla species has been identified (Aoyama, 2009). In Indonesia waters, approximately five to seven species and 
subspecies were discovered (Wouthuyzen et al., 2009). However, some other studies reported that nine of them inhabit these waters, namely A. celebesensis, A. marmorata, A. borneensis, A. interioris, A. obscura, A. bicolor bicolor, A. bicolor pacifica, A. nebulosa nebulosa, and A. megastoma (Sugeha, 2010; Sugeha \& Arai, 2010; Sugeha \& Genisa, 2015).

An entirely different number was detected in the Western and Eastern Indonesia Region. According to Sugeha et al. (2008), A. nebulosa nebulosa and A. bicolor bicolor inhabit the Western waters, while A. marmorata. A. celebesensis. A. bicolor pacifica, and A. interiori are found in the Eastern part (Sugeha, 2010; Sugeha \& Arai, 2010). However, a recent study carried out in the Aceh waters by Muchlisin et al. (2017) reported an additional species, namely A. bengalensis. Therefore, in total, three Anguilla species, A. bicolor, A. marmorata and $A$. bengalensis were discovered in the Aceh waters. Fahmi (2015), also discovered three Anguilla species, although the third one was different from that reported by Muchlisin et al., (2017). Conversely, instead of A. bengalensis, A. nebulosa was discovered.

A different number of species were also reported in the studies carried out in the Southern Areas of West and Central Java (Rachmawati \& Susilo, 2011; Minegishi et al., 2012; Tanaka et al., 2014; Fahmi, 2015). Fahmi (2015) discovered three Anguilla species in Pelabuhan Ratu, A. bicolor, A. marmorata, and A. nebulosa. Furthermore, Tanaka et al. (2014) discovered only one eels species, A. bicolor. Rachmawati \& Susilo (2011) and Fahmi (2015) reported that one of the species inhabit the Cilacap waters. In addition, Fahmi (2015) collected Anguilla from the same site. However, such a minimal number of sample sites is considered unreliable for scientific purposes and eel fisheries management.

Therefore, critical problems related to eel fishery management in Cilacap, such as taxonomic status and population genetics of Anguilla in rivers across Cilacap Regency, particularly those belonging to the Segara Anakan watersheds need to be resolved. These issues are assessed by studying molecular characterization using cytochrome $c$ oxidase subunit 1 (COI) gene as a marker. Although, previous studies have proven that COI gene is a reliable marker for molecular identification (Matarese et al., 2011; Hubert et al., 2012; Pereira et al., 2013; Nuryanto et al., 2017; Bhagawati et al., 2020). In addition, phylogeographic research also reported a similar discovery (Song et al., 2013; Zhang et al., 2014; Nuryanto et al., 2019). It was considered a reliable marker for eel's molecular characterization, Anguilla (Fahmi, 2015; Muchlisin et al., 2017).

This study aims to determine the taxonomic status and molecular characteristics of Anguilla specimens collected at Sapuregel and Cibeureum Rivers, as well as Segara Anakan watersheds Cilacap, Central Java.

\section{MATERIALS AND METHODS}

Sampling time and sites. Samples were bought in June 2020, from the first collectors residing at Kubangkangkung Hamlet, District of Kawunganten, and Pondok Lombok Hamlet, Kaliwungu Village, District of Kedungreja, Cilacap Regency (Fig. 1). The first collector from Kubangkangkung Hamlet bought it from the fishermen that captured it in Sapuregel River Watersheds. In contrast, the one from Pondok Lombok Hamlet obtained it from fishermen that caught it in Cibeureum River Watersheds. Subsequently, both sampling sites empty into the Segara Anakan watersheds.

\section{Genomic DNA isolation, marker} amplification, and sequencing. Approximately $2 \times 2$ millimeter square of dorsal fin tissue samples were sent to PT. Genetika Science Indonesia for DNA analysis. The total genomic DNA was isolated using the gSYNCTM DNA extraction kit (Geneaid, GS050) by adhering to the company's directives. The amplification of the COI fragment was carried out using KOD FXNeo (Toyobo, KFX201). The COI marker was amplified using the following primer sets, VF2_t1

TGTAAAACGACGGCCAGTCAACCAACCACAA AGACATTGGCAC, FishF2 t1 TGTAAAACGACGGCCAGTCGACTAATCATAA AGATATCGGCAC, $\quad$ FishR2 t1 CAGGAAACAGCTATGACACTTCAGGGTGACC 
GAAGAATCAGAA, and FR1d t 1 CAGGAAACAGCTATGACACCTCAGGGTGTCC GAARAAYCARAA. The final volume of PCR reactions was obtained as $25 \mu 1$, and each reagent's composition is presented in Table 1 .

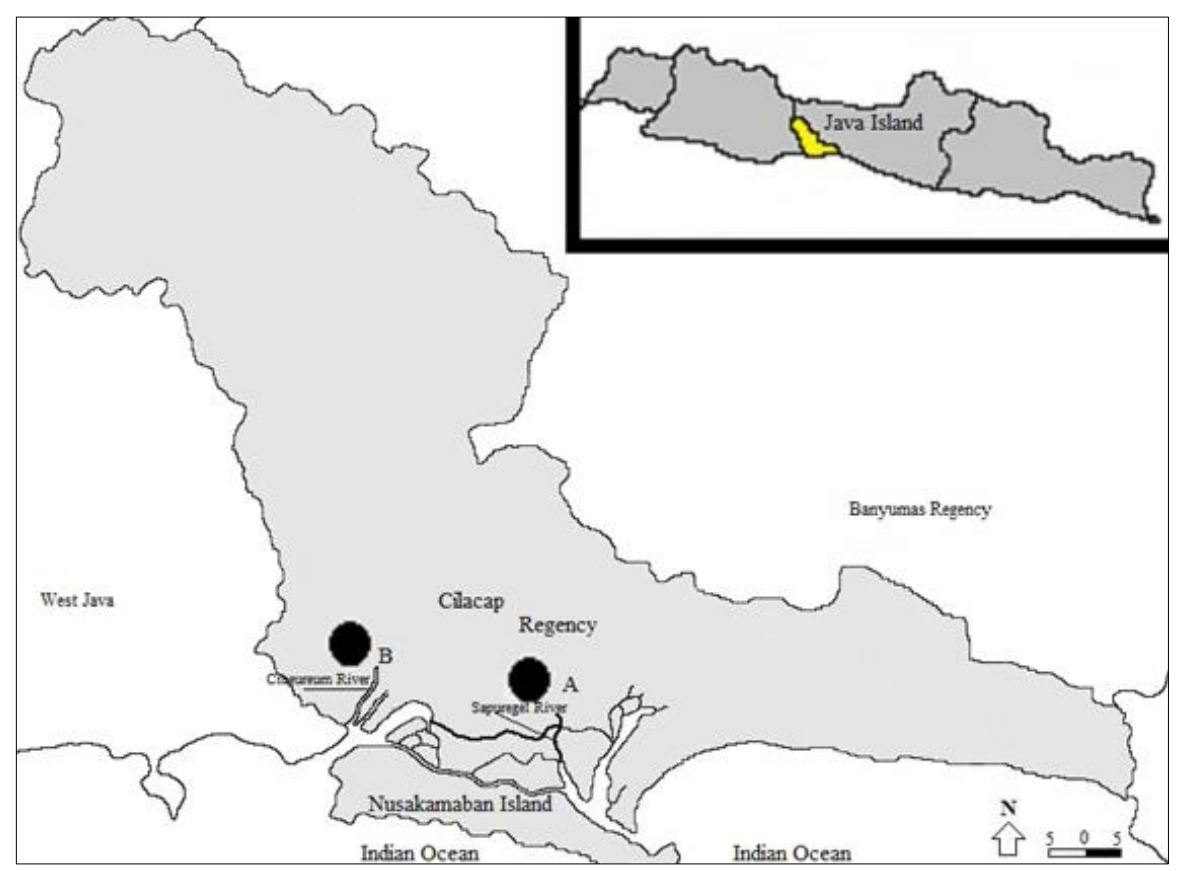

Fig. 1. Sampling sites for Anguilla collection.

The thermal conditions for PCR amplification involved an initial denaturation realized at $96^{\circ} \mathrm{C}$, which lasted for $3 \mathrm{~min}$. It was further carried out at $94^{\circ} \mathrm{C}$ for $10 \mathrm{~s}$, annealing at $52^{\circ} \mathrm{C}$ for $30 \mathrm{~s}$, and extension at $72^{\circ} \mathrm{C}$ for $45 \mathrm{~s}$. It was repeated in a circular motion 35 times, and this was ended by holding the cycler at $4{ }^{\circ} \mathrm{C}$. Conversely, the PCR amplification was carried out on Agilent Surecycler 8800. Furthermore, the clear and strong products were subjected to bidirectional sequencing.

Table 1. Reagent composition for COI marker amplification.

\begin{tabular}{lll}
\hline No & Reagent & Volume in $25 \mu \mathrm{l}$ \\
\hline 1 & ddH2O & 4 \\
2 & KOD FX Neo & 1 \\
3 & 2x PCR Buffer KOD FX & 12.5 \\
& Neo & \\
4 & $2 \mathrm{mM} \mathrm{dNTPs}$ & 2.5 \\
5 & $10 \mathrm{pmol} / \mu 1$ Primer VF2_t1 & 1 \\
6 & $\begin{array}{l}10 \mathrm{pmol} / \mu 1 \text { Primer } \\
\text { FishF2_t1 }\end{array}$ & 1 \\
7 & $\begin{array}{l}10 \mathrm{pmol} / \mu 1 \text { Primer } \\
8\end{array}$ & $\begin{array}{l}\text { FishR2_t1 } \\
10 \mathrm{pmol} / \mu 1 \text { Primer FR1d_t1 }\end{array}$ \\
& & 1 \\
9 & Template DNA & 1 \\
\hline
\end{tabular}

Sequence editing and data analysis. The forward and reverse sequences of each sample were contiged and edited in Bioedit version 7.0.4.1 (Hall, 2011). This was carried out in to obtain a consensus sequence. Its alignment was performed using ClustalW in Bioedit version 7.0.4.1 (Hall, 2011). The COI sequences of the samples were deposited in GenBank (accession number MT883612-MT883625).

Taxonomic status. Conservation statuses of the samples were determined based on homology, genetic divergences, and the distance to the reference species deposited in GenBank, including their monophyly. The value of the homology is obtained by comparing the available reference species in the GenBank. Genetic divergence was calculated based on the Juke-Cantor substitution model in DnaSP6 (Rozas et al., 2017). The homology test was carried out using a basic local alignment online search tool (BLAST) NCBI. The monophyly of Anguilla samples in accordance with the reference species was inferred from the cladogram, which was developed using neighbor-joining (NJ) and maximum likelihood (ML) algorithms in 
MEGA X (Kumar et al., 2018). The reliability of tree topology was obtained from 1000 bootstraps pseudoreplicates. Subsequently, the branching pattern's polarity was realized from the comparison, of the out-group specimen Muraenesox bagio (MK041057).

Population genetics. The population genetics of the species recovered in Cibeureum and Sapuregel Rivers watersheds were assessed based on genetic divergence, polymorphic sites, haplotype, and nucleotide diversity. Polymorphism and genetic divergences within populations were estimated using the JukeCantor substitution model implemented in DnaSP version 6 (Rozas et al., 2017).
Haplotype and nucleotide diversity were calculated using Arlequin 3.5 (Excoffier \& Lischer, 2010).

\section{RESULTS AND DISCUSSION}

Taxonomic status. The results from BLAST showed that the samples used in this study have sequence identity values ranging from $99.23 \%$ to $99.84 \%$. The Anguilla bicolor in GenBank encompasses sequences queries ranging from $96 \%$ to $99 \%$ and an error value of 0.00. The detailed BLAST parameter of the samples in accordance with the reference species is shown in Table 2.

Table 2. BLAST parameters of Anguilla samples to the reference species.

\begin{tabular}{|c|c|c|c|c|c|c|c|c|}
\hline Code & $\begin{array}{l}\text { Accession } \\
\text { Number }\end{array}$ & $\begin{array}{l}\text { Max } \\
\text { Score }\end{array}$ & $\begin{array}{l}\text { Total } \\
\text { Score }\end{array}$ & $\begin{array}{l}\text { Query } \\
\text { Cover }\end{array}$ & E-value & Identity & Reference Species & $\begin{array}{l}\text { Accession } \\
\text { number }\end{array}$ \\
\hline Kja01 & MT883612 & 1162 & 1162 & 98 & 0.00 & 99.38 & Anguilla bicolor & AP007236 \\
\hline $\mathrm{Kja02}$ & MT883613 & 1162 & 1162 & 98 & 0.00 & 99.38 & Anguilla bicolor & AP007236 \\
\hline $\mathrm{Kja03}$ & МT883614 & 1168 & 1168 & 99 & 0.00 & 99.53 & Anguilla bicolor & AP007236 \\
\hline $\mathrm{Kja04}$ & MT883615 & 1162 & 1162 & 99 & 0.00 & 99.84 & Anguilla bicolor & AP007236 \\
\hline Kja05 & MT883616 & 1173 & 1173 & 98 & 0.00 & 99.69 & Anguilla bicolor & AP007236 \\
\hline $\mathrm{Kja06}$ & MT883617 & 1164 & 1164 & 96 & 0.00 & 99.84 & Anguilla bicolor & KM875505 \\
\hline Kja07 & MT883618 & 1168 & 1168 & 98 & 0.00 & 99.53 & Anguilla bicolor & AP007236 \\
\hline Kja08 & MW080739 & 1140 & 1140 & 100 & 0.00 & 99.84 & Anguilla bicolor & KM875504 \\
\hline Kja09 & MW078537 & 1134 & 1134 & 99 & 0.00 & 99.84 & Anguilla bicolor & MG675613 \\
\hline Kja11 & MW078538 & 1134 & 1134 & 100 & 0.00 & 99.68 & Anguilla bicolor & KP979655 \\
\hline Kja12 & MW078539 & 1147 & 1147 & 100 & 0.00 & 100 & Anguilla bicolor & KU692247 \\
\hline Kja13 & MW080740 & 1155 & 1155 & 100 & 0.00 & 99.53 & Anguilla bicolor & AP007236 \\
\hline Kja15 & MW078540 & 1123 & 1123 & 100 & 0.00 & 99.35 & Anguilla bicolor & KP979655 \\
\hline Kwt01 & MW078541 & 1096 & 1096 & 100 & 0.00 & 100 & Anguilla bicolor & KY618776 \\
\hline Kwt03 & MW080741 & 1153 & 1153 & 99 & 0.00 & 99.68 & Anguilla bicolor & AP007236 \\
\hline Kwt04 & МТ883619 & 1173 & 1173 & 98 & 0.00 & 99.38 & Anguilla bicolor & AP007236 \\
\hline Kwt06 & MT883620 & 1168 & 1168 & 99 & 0.00 & 99.23 & Anguilla bicolor & AP007236 \\
\hline Kwt07 & MW080742 & 1127 & 1127 & 99 & 0.00 & 99.84 & Anguilla bicolor & KU692247 \\
\hline Kwt08 & MT883621 & 1162 & 1162 & 99 & 0.00 & 99.84 & Anguilla bicolor & AP007236 \\
\hline Kwt09 & MT883622 & 1234 & 1234 & 98 & 0.00 & 99.41 & Anguilla bicolor & AP007236 \\
\hline Kwt10 & МТ883623 & 1173 & 1173 & 98 & 0.00 & 99.38 & Anguilla bicolor & AP007236 \\
\hline Kwt12 & MT883624 & 1173 & 1173 & 98 & 0.00 & 99.38 & Anguilla bicolor & AP007236 \\
\hline Kwt13 & MW078542 & 1129 & 1129 & 100 & 0.00 & 99.52 & Anguilla bicolor & KP979655 \\
\hline Kwt14 & MW078543 & 1092 & 1092 & 99 & 0.00 & 99.83 & Anguilla bicolor & KY618771 \\
\hline Kwt16 & MT883625 & 1229 & 1229 & 98 & 0.00 & 99.26 & Anguilla bicolor & AP007236 \\
\hline
\end{tabular}

The BLAST parameters of the samples, shown in Table 2, absolutely align with the Anguilla bicolor. Therefore, it was concluded that the eel samples collected at Cibeureum and Sapuregel River watersheds are categorized as Anguilla bicolor. This decision was made based on the fact that all the samples' values were higher than $97 \%$, which commonly serves as the threshold for genetic identity (Ko et al., 2013). In some instances, it tends to be lower than $97 \%$ depending on the fish groups (Pereira et al., 2013; Ratnasingham \& Hebert, 2013).

The present research realized a similar number of $A$. bicolor species from Segara Anakan estuary. However, this is consistent with the previous studies carried out by Fahmi (2015), and Rachmawati \& Susilo (2011). These similarities confirm and strengthen the hypotheses reported in previous studies that the species of eel discovered in Segara Anakan 
waters is A. bicolor and also indicates as dominant species that inhabits Cilacap waters, particularly the Cibeureum and Sapuregel River watersheds which empty into Segara Anakan. The result from this analysis is reasonable hence A. bicolor is commonly restricted to Cibeureum and Sapuregel, which are lowland river systems and are rarely found in large upland streams (Froese \& Pauly, 2019).

Subsequently, when compared to studies carried out in the Indian Ocean near Java and Sumatera, it was discovered that the present research obtained a different number of species as reported by Fahmi \& Hirnawati (2010) and
Muchlisin et al. (2017). This is due to the differences in the study areas. Conversely, this research is focused on Cibeureum and Sapuregel rivers watersheds which empty into the Segara Anakan estuary, while Fahmi \& Hirnawati (2010) carried out a study on the species composition at Cimandiri River, Sukabumi. These rivers possess different characteristics. Cibeureum and Sapuregel Rivers are typically short $(40 \mathrm{~km})$ lowlands with its spring in Gunungsari Hill, which is only 260 masl, and they are typical habitats for $A$. bicolor.

Table 3. Genetic divergences among samples and reference species (A. bicolor).

\begin{tabular}{|c|c|c|c|c|c|c|c|c|c|}
\hline \multirow{2}{*}{ No } & \multirow{2}{*}{$\begin{array}{l}\text { Sample } \\
\text { Code }\end{array}$} & \multicolumn{8}{|c|}{ The accession number of reference species $(\%)$} \\
\hline & & KM875504 & KP979655 & KY618776 & KU692247 & KY618771 & AP007236 & MG675613 & KM875505 \\
\hline 1 & $\mathrm{Kja01}$ & 1.1475 & 0.1897 & 0.9544 & 0.9544 & 0.1897 & 0.38022 & 0.1897 & 0.9544 \\
\hline 2 & $\mathrm{Kja02}$ & 0.9544 & 0.0000 & 0.7622 & 0.7622 & 0.0000 & 0.1897 & 0.0000 & 0.7622 \\
\hline 3 & $\mathrm{Kja} 03$ & 0.9544 & 0.0000 & 0.7622 & 0.7622 & 0.0000 & 0.1897 & 0.0000 & 0.7622 \\
\hline 4 & $\mathrm{Kja04}$ & 0.9544 & 0.0000 & 0.7622 & 0.7622 & 0.0000 & 0.1897 & 0.0000 & 0.7622 \\
\hline 5 & $\mathrm{Kja} 05$ & 1.1475 & 0.1897 & 0.9544 & 0.9544 & 0.1897 & 0.000 & 0.1897 & 0.9544 \\
\hline 6 & Kja06 & 0.3802 & 0.5706 & 0.1897 & 0.1897 & 0.5706 & 0.7622 & 0.5706 & 0.1897 \\
\hline 7 & $\mathrm{Kja07}$ & 0.9544 & 0.0000 & 0.7622 & 0.7622 & 0.0000 & 0.1897 & 0.0000 & 0.7622 \\
\hline 8 & $\mathrm{Kja08}$ & 0.1897 & 1.1475 & 0.3802 & 0.3802 & 1.1475 & 1.3413 & 1.1475 & 0.3802 \\
\hline 9 & $\mathrm{Kja09}$ & 0.9544 & 0.0000 & 0.7622 & 0.7622 & 0.0000 & 0.1897 & 0.0000 & 0.7622 \\
\hline 10 & Kja11 & 0.9544 & 0.0000 & 0.7622 & 0.7622 & 0.0000 & 0.1897 & 0.0000 & 0.7622 \\
\hline 11 & Kja12 & 0.1897 & 0.7622 & 0.0000 & 0.0000 & 0.7622 & 0.9544 & 0.7622 & 0.0000 \\
\hline 12 & Kja13 & 1.1475 & 0.1897 & 0.9534 & 0.9534 & 0.1897 & 0.3798 & 0.1897 & 0.9534 \\
\hline 13 & Kja15 & 1.3413 & 0.3802 & 1.1475 & 1.1475 & 0.3802 & 0.5714 & 0.3802 & 1.1475 \\
\hline 14 & Kwt01 & 0.1897 & 0.7622 & 0.0000 & 0.0000 & 0.7622 & 0.9544 & 0.7622 & 0.0000 \\
\hline 15 & Kwt03 & 1.1475 & 0.1897 & 0.9544 & 0.9544 & 0.1897 & 0.3802 & 0.1897 & 0.9544 \\
\hline 16 & Kwt04 & 0.9544 & 0.0000 & 0.7622 & 0.7622 & 0.0000 & 0.1897 & 0.0000 & 0.7622 \\
\hline 17 & Kwt06 & 1.1475 & 0.1897 & 0.9544 & 0.9544 & 0.1897 & 0.3802 & 0.1897 & 0.9544 \\
\hline 18 & Kwt07 & 0.3802 & 0.9544 & 0.1897 & 0.1897 & 0.9544 & 1.1475 & 0.9544 & 0.1897 \\
\hline 19 & Kwt08 & 0.9544 & 0.0000 & 0.7622 & 0.7622 & 0.0000 & 0.1897 & 0.0000 & 0.7622 \\
\hline 20 & Kwt09 & 0.9544 & 0.0000 & 0.7622 & 0.7622 & 0.0000 & 0.1897 & 0.0000 & 0.7622 \\
\hline 21 & Kwt10 & 0.9544 & 0.0000 & 0.7622 & 0.7622 & 0.0000 & 0.1897 & 0.0000 & 0.7622 \\
\hline 22 & Kwt12 & 0.9544 & 0.0000 & 0.7622 & 0.7622 & 0.0000 & 0.1897 & 0.0000 & 0.7622 \\
\hline 23 & Kwt13 & 1.1475 & 0.1897 & 0.9544 & 0.9544 & 0.1897 & 0.3802 & 0.1897 & 0.9544 \\
\hline 24 & Kwt14 & 0.9544 & 0.0000 & 0.7622 & 0.7622 & 0.0000 & 0.1897 & 0.0000 & 0.7622 \\
\hline 25 & Kwt16 & 0.9544 & 0.0000 & 0.7622 & 0.7622 & 0.0000 & 0.1897 & 0.0000 & 0.7622 \\
\hline
\end{tabular}

In contrast, Cimandiri is regarded both as a lowland and upland river running from several mountains (Gede, Pangrango, Halimun, and Salak) at the height of approximately 1200 masl. It is a suitable habitat for several Anguilla species, and this type of characteristics is also similar to the Aceh rivers (Muchlisin et al., 2017). According to Froese \& Pauly (2019), A. marmorata, A. nebulosa, and A. bengalensis are found in such rivers. The differences in characteristics are ideal, and the present study was only able to discover A. bicolor. Fahmi \& Hirnawati (2010) and Muchlisin et al. (2017) discovered three Anguilla species.

The BLAST results are supported by the values of the genetic or molecular divergence of the samples and A. bicolor in GenBank, which ranges from $0.224 \%$ to $1.127 \%$. A detailed description of these values for all individual species and the reference $A$. bicolor sequences are shown in Table 3 . They were discovered to be within the range of $0.1 \%$ to 
$6.0 \%$ which is below the genetic divergences threshold for fish species identity in Canada and Australia (Ratnasingham \& Hebert, 2013). The values obtained are also within the range reported by Pegg et al. (2006), which is from $1 \%$ to $3 \%$. Furthermore, the genetic divergences realized in this research are far below the maximum value reported by Pereira et al. (2013), which was $8.5 \%$. In addition, this is also consistent with previous studies (Muchlisin et al., 2017; Nuryanto et al., 2017a; Nuryanto et al., 2017b; Nuryanto et al., 2018). Therefore, it is compelling that the low genetic divergence values of eel samples and A. bicolor sequences in GenBank prove that the species from Cibeureum and Sapuregel River watersheds belong to the A. bicolor.

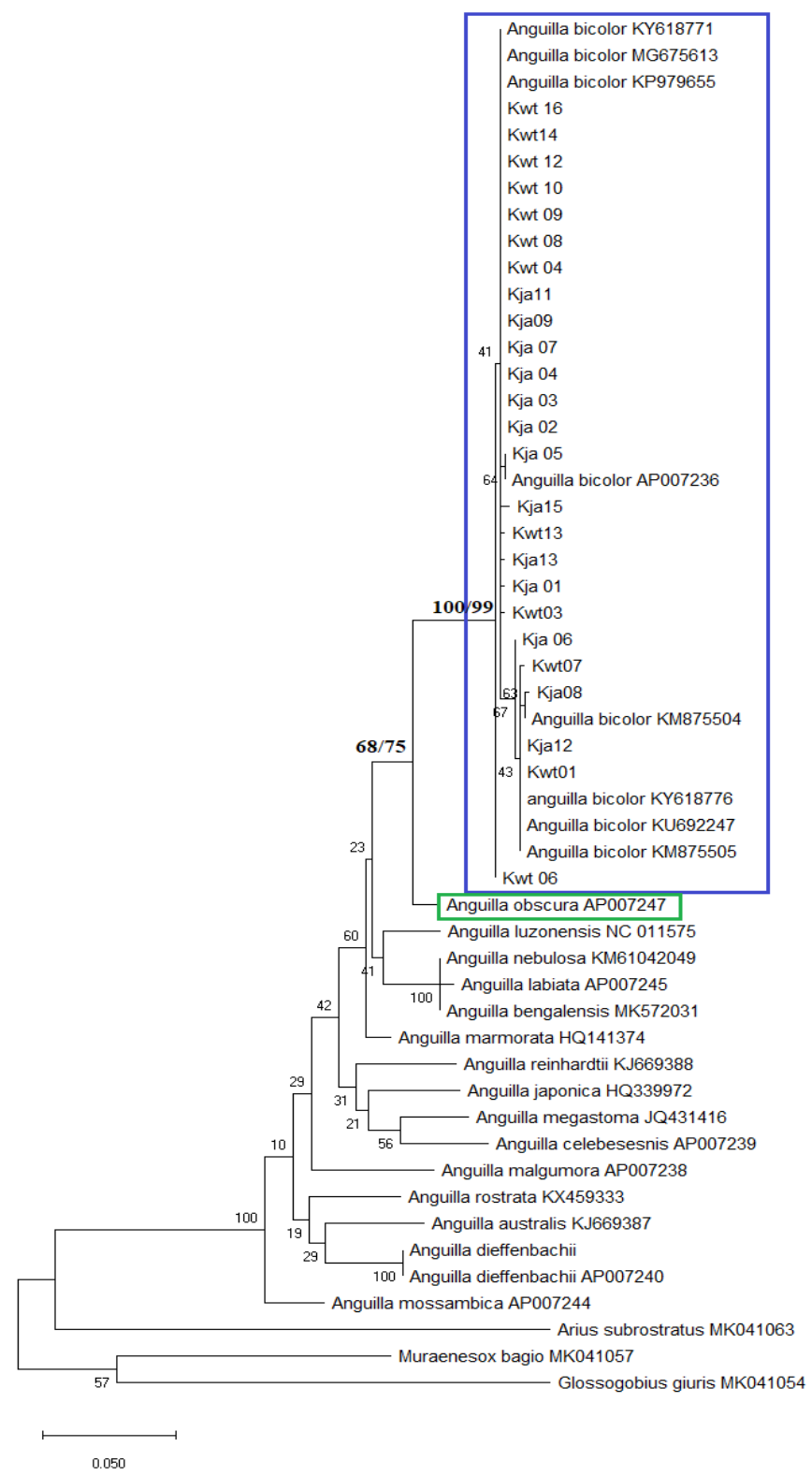

Fig. 2. Taxonomic tree showing the monophyly of the samples to the references species in GenBank and separation to sister taxon (A. obscura). Left: ML bootstrap values; Right: NJ bootstrap values.

The cladogram in Fig. 2 showed that the eel samples collected from Cibeureum and Sapuregel River watersheds belonged to the monophyletic, clade or Anguilla bicolor group retrieved from the GenBank (Blue box). It is also evident in Fig. 2 that these samples are separated from its sister taxon, A. obscura (green box). Its monophyly, in accordance with their reference species, was supported by high bootstrap values $(\mathrm{ML}=99 ; \mathrm{NL}=100)$. The 
separation of the sample clade from their sister taxon was also triggered by high bootstraps values $(\mathrm{ML}=81 ; \mathrm{NJ}=78)$.

The monophyly of the samples and $A$. bicolor from GenBank shows extremely low genetic distances (the branch length in Fig. 2). A clear separation of the sample clade from its sister taxon ( $A$. obscura) provides additional data which stated that species from Cibeureum and Sapuregel River watersheds are genetically identified as bicolor. The result also showed that the COI gene is a reliable marker for species identification. Its reliability also serves as a barcode marker which varies among species, due to its high mutation rate (Sachithanandam et al., 2012). This is also consistent with the research carried out by Muchlisin et al. (2017), or studies related to the strain in fish species (Nuryanto et al., 2018) and also in Crustacea (Bhagawati et al., 2020).

Based on the BLAST parameters, genetic divergence, and monophyly of the samples, was categorized as Anguilla bicolor. The taxonomic status of eel samples is shown in Table 4.

Table 4. Taxonomic status of the Anguilla samples.

\begin{tabular}{|c|c|c|c|c|}
\hline Code & Ordo & Familia & Genus & Species \\
\hline Kja01 & Anguilliformes & Anguillidae & Anguilla & Anguilla bicolor \\
\hline $\mathrm{Kja02}$ & Anguilliformes & Anguillidae & Anguilla & Anguilla bicolor \\
\hline Kja03 & Anguilliformes & Anguillidae & Anguilla & Anguilla bicolor \\
\hline $\mathrm{Kja04}$ & Anguilliformes & Anguillidae & Anguilla & Anguilla bicolor \\
\hline Kja05 & Anguilliformes & Anguillidae & Anguilla & Anguilla bicolor \\
\hline Kja06 & Anguilliformes & Anguillidae & Anguilla & Anguilla bicolor \\
\hline Kja07 & Anguilliformes & Anguillidae & Anguilla & Anguilla bicolor \\
\hline Kja08 & Anguilliformes & Anguillidae & Anguilla & Anguilla bicolor \\
\hline Kja09 & Anguilliformes & Anguillidae & Anguilla & Anguilla bicolor \\
\hline Kja11 & Anguilliformes & Anguillidae & Anguilla & Anguilla bicolor \\
\hline Kja12 & Anguilliformes & Anguillidae & Anguilla & Anguilla bicolor \\
\hline Kja13 & Anguilliformes & Anguillidae & Anguilla & Anguilla bicolor \\
\hline Kja15 & Anguilliformes & Anguillidae & Anguilla & Anguilla bicolor \\
\hline Kwt01 & Anguilliformes & Anguillidae & Anguilla & Anguilla bicolor \\
\hline Kwt03 & Anguilliformes & Anguillidae & Anguilla & Anguilla bicolor \\
\hline Kwt04 & Anguilliformes & Anguillidae & Anguilla & Anguilla bicolor \\
\hline Kwt06 & Anguilliformes & Anguillidae & Anguilla & Anguilla bicolor \\
\hline Kwt07 & Anguilliformes & Anguillidae & Anguilla & Anguilla bicolor \\
\hline Kwt08 & Anguilliformes & Anguillidae & Anguilla & Anguilla bicolor \\
\hline Kwt09 & Anguilliformes & Anguillidae & Anguilla & Anguilla bicolor \\
\hline Kwt10 & Anguilliformes & Anguillidae & Anguilla & Anguilla bicolor \\
\hline Kwt12 & Anguilliformes & Anguillidae & Anguilla & Anguilla bicolor \\
\hline Kwt13 & Anguilliformes & Anguillidae & Anguilla & Anguilla bicolor \\
\hline Kwt14 & Anguilliformes & Anguillidae & Anguilla & Anguilla bicolor \\
\hline Kwt16 & Anguilliformes & Anguillidae & Anguilla & Anguilla bicolor \\
\hline
\end{tabular}

Population Genetics. Molecular identification categorized all samples as $A$. bicolor. This served as the basis for the analysis of population genetics in both sampling sites. Multiple sequence alignment resulted in 630 base pairs (bp) fragment of the COI gene. However, 7 of them are polymorphic sites with a value of $1.111 \%$. This simply means that the most common allele has a frequency of $98.99 \%$. In addition, this value shows a decline in the polymorphism of the COI gene of Anguilla bicolor collected at the two river watersheds that empty into the Segara Anakan Estuary. It is because the value is less than $5 \%$, which implies that the most common allele has a higher frequency than 95\%. According to Nuryanto et al. (2019), a gene is said to be polymorphic supposing it has a common allele with a maximum frequency of $95 \%$.

The overall haplotype and nucleotide diversities were $0.681 \pm 0.132$, and $0.160 \% \pm 0.124$, respectively. The total haplotype diversity shows that the COI gene of A. bicolor collected at the river watersheds that empty into Segara Anakan has a medium level of genetic diversity. According to Nei (1987), its values range between 0.50 and 0.7 . In contrast, the value of nucleotide diversity 
realized is classified as low. It is reasonable that a low value was discovered in A. bicolor's COI gene in the Cibeureum and Sapuregel watersheds because it encompasses only seven polymorphic sites total of 630 locations that were analyzed. Nei (1987) reported that the nucleotide diversity value below $1 \%$ is categorized as low.

Genetic diversity analysis showed that the Cibeureum and Sapuregel River watershed populations have haplotype diversities of $0.857 \pm 0.137$, and $0.524 \pm 0.209$, respectively. This shows that the A. bicolor from Cibeureum and Sapuregel watersheds has high haplotype and medium nucleotide diversities. This was because the value of the haplotype diversity in the Cibeureum watershed was slightly higher than 0.8, while in Sapuregel, it was approximately 0.5 and 0.7 . According to Nei (1987), the values of haplotype diversity range between 0.5 to 0.7 in the medium category. On the contrary, a high value lies within the range of 0.8 and 1.0. The result showed that a complex pattern of genetic diversity is a common phenomenon in the natural population. The High and low haplotype genetic diversity levels have been reported in various animal groups ranging from bivalve, gastropod, insects to fish (Díaz-Ferguson et al., 2010; Dorn et al., 2011; Pavesi et al., 2011; Sabando et al., 2011; Dung et al., 2013; Song et al., 2013; Zhang et al., 2014; Liu et al., 2017; Parmaksiz \& Eksi, 2017).

Based on the nucleotide level, the Cibeureum and Sapuregel watershed populations have a diversity of $0.245 \% \pm 0.185$, and $\quad 0.082 \% \quad \pm 0.085, \quad$ respectively. Subsequently, these values show that both populations had low nucleotide diversity. This was due to the fact that the values obtained were below $1 \%$. According to Kochzius \& Nuryanto (2008), it depicts low nucleotide diversity.

The values obtained imply that $A$. bicolor from Cibeureum watershed has higher genetic diversity than those from Sapuregel. It is due to the fact that both rivers have different physical characteristics, such as the width and length of the watersheds, which leads to diverse riverscape. It was reported that a positive correlation exists between genetic diversity and the riverscape of various organisms (Cook et al., 2011; Olsen et al., 2011; Cooke et al., 2014; Brauer et al., 2016; Davis et al., 2018). Based on this observation, Cibeureum watersheds are broader and longer as well as have more scapes than Sapuregel. Therefore, it is reasonable to state that $A$. bicolor population in Cibeureum watersheds has higher genetic diversity than the species in Sapuregel.

Sequentially, the decline in polymorphisms, medium and low haplotype and nucleotide diversities of Anguilla's COI gene in this research indicate that there are no genetic differences between the two watersheds. This is proven by the low level of genetic divergence between the samples from Sapuregel and Cibeureum Rivers watershed, which was obtained as $0.175 \%$. It is due to the fact that historically both populations were reproduced from a similar maternal A. bicolor which tend to spawn at a particular site in the Indian Ocean. There is a high possibility that individual species returned to both watersheds were their eggs were hatched by a single maternal A. bicolor. Therefore, they were reported to have similar molecular constituents in their COI gene because it is inherited. According to Hebert et al., (2003), COI is a mitochondrial genome inherited from the maternal line. Conversely, it is used for maternity analysis and shows high similarity in closed populations.

Table 5. The amova analysis.

\begin{tabular}{lllll}
\hline $\begin{array}{l}\text { Source of } \\
\text { variation }\end{array}$ & df & $\begin{array}{l}\text { Sum of } \\
\text { Squares }\end{array}$ & $\begin{array}{l}\text { Var. } \\
\text { Component }\end{array}$ & $\begin{array}{l}\text { \% of } \\
\text { Variation }\end{array}$ \\
\hline $\begin{array}{l}\text { Among } \\
\text { populations }\end{array}$ & 1 & 0.372 & $-0.004 \mathrm{Va}^{\mathrm{ns}}$ & -1.03 \\
$\begin{array}{l}\text { Within } \\
\text { populations }\end{array}$ & 23 & 9.788 & $0.426 \mathrm{Vb}$ & 101.03 \\
$\begin{array}{l}\text { Total } \\
\text { Fixation }\end{array}$ & 24 & 10.160 & 0.430 & \\
$\begin{array}{l}\text { Index FST } \\
\text { p-value }\end{array}$ & $=$ & $\begin{array}{l}0.0103^{\mathrm{ns}} \\
0.535 \pm\end{array}$ & & \\
& & 0.016 & & \\
\hline
\end{tabular}

Notes: $\mathrm{ns}=$ non significant

However, genetic differences were not discovered in both populations, as shown in the amova analysis (Table 5). Based on Table 4, the variance component (Va) among the populations was realized as -0.009 ( $\mathrm{p}$-value $=$ 
0.761) while the genetic fixation index (Fst) was $-.025(p$-value $=0.761)$. Both values show that no genetic structure or difference was discovered between Cibeureum and Sapuregel Watersheds. It simply means that $A$. bicolor in the Segara Anakan Cilacap is a single population.

Surprisingly, the present study was unable to observe genetic differences between the two river systems. Generally, riverine populations tend to show significant genetic differences (Hughes et al., 2009) which is also observed among tributaries without physical barriers (Kanno et al., 2011). However, since A. bicolor from both river watersheds spawned in the same areas in the Indian Ocean, therefore the absence of genetic differences is a normal phenomenon.

Furthermore, genetic differences were not observed in the commerson anchovy across the Segara Anakan estuary (Nuryanto et al., 2019). This is consistent with the studies related to the Hemibagrus nemurus, while the other populations showed significant genetic structure (Nuryanto et al., 2019). Significant genetic differences among populations were discovered in some fish species (Pavesi et al., 2011; Dung et al., 2013). Some studies that adopted microsatellite markers which are believed to be more sensitive than the COI gene also showed variable results. On the contrary, genetic differences among the fish populations were not detected (Damerau et al., 2012; Basharat et al., 2016). Conversely, studies using microsatellite also showed significant genetic differences among populations (Bartáková et al., 2013; Esa \& Rahim, 2013; Abbas et al., 2017; Yan et al., 2018). However, both present and previous studies reported that genetic differentiation among the natural populations is complex, irrespective of the adopted genetic markers.

The medium to relatively high genetic diversity and the absence of genetic differences in the watersheds have important implications for the conservation of $A$. bicolor. It is suggested that $A$. bicolor resources in the Segara Anakan watershed need to be managed as an enormous single population, however, this means that Segara Anakan Cilacap needs to be conserved as a unit. Nevertheless, additional samples and genetic markers are required to provide more reliable information on $A$. bicolor's molecular characterization in the Segara Anakan watershed which tends to be used as the scientific basis for the conservation of Anguilla in Segara Anakan. Moreover, additional information, such as catchment areas and rates of $A$. bicolor, social-economic, and ecological data, is required to provide the actual number of this species in Segara Anakan. Therefore, conservation policy needs to be made based on a firm scientific basis.

\section{CONCLUSION}

In conclusion, Anguilla bicolor is the only eel species that inhabit river watersheds around Segara Anakan Cilacap. It has medium to high genetic diversity, lacks genetic differences and formed a single genetic conservation unit across Segara Anakan.

\section{ACKNOWLEDGEMENTS}

The authors are grateful to the Universitas Jenderal Soedirman for funding this study through the research scheme Riset Unggulan Terapan Unsoed (contract number: P/234/UN23.18/PT.01.03/2020). The authors are also grateful to the Research and Public Service Institute and Biology Faculty of Universitas Jenderal Soedirman for the facilities provided for the research to be carried out and to the editors as well as reviewers for valuable input and comments provided in this manuscript.

\section{REFERENCES}

Abbas K, Xiaoyun Z, Weimin W. 2017. Microsatellite markers reveal genetic differentiation of Chinese dojo loach Misgurnus anguillicaudatus in the Yangtze River Basin. Turkish Journal of Fisheries and Aquatic Sciences. vol 17: 1167-1177. doi: https://doi.org/10.4194/1303-2712-v17.

Aoyama J. 2009. Life history and evolution of migration in catadromous eels (Genus Anguilla). AquaBioScience Monographs. vol 2(1): 1-42. doi: https://doi.org/10.5047/absm.2009.00201.0001.

Bartáková V, Reichard M, Janko K, Polačik M, Blažek R, Reichwald K, Cellerino A, Bryja J. 2013. Strong population genetic structuring in an annual fish, Nothobranchius furzeri, suggests multiple savannah refugia in southern Mozambique. BMC 
Evolutionary Biology. vol 13(1): 1-15. doi: https://doi.org/10.1186/1471-2148-13-196.

Basharat H, Ghafoor A, Chavhan A, Zafar M, Abbas K, Parveen J. 2016. Microsatellite markers revealed poor genetic structure of Wallago Attu in Punjab, Pakistan. International Journal of Life Sciences. vol 4(3):385-393.

Bhagawati D, Winarni ET, Nuryanto A. 2020. Molecular barcoding reveals the existence of mole crabs Emerita emeritus in the north coast of Central Java. Biosaintifika: Journal of Biology \& Biology Education. vol 12(1): 104-110. doi: https://doi.org/10.15294/biosaintifika.v12i1.20497.

Brauer CJ, Hammer MP, Beheregaray LB. 2016. Riverscape genomics of a threatened fish across a hydroclimatically heterogeneous river basin. Molecular Ecology. vol 25(20): 5093-5113. doi: https://doi.org/10.1111/mec.13830.

Cook BD, Kennard MJ, Real K, Pusey BJ, Hughes JM. 2011. Landscape genetic analysis of the tropical freshwater fish Mogurnda mogurnda (Eleotridae) in a monsoonal river basin: importance of hydrographic factors and population history. Freshwater Biology. vol 56(5): 812-827. doi: https://doi.org/10.1111/j.1365-2427.2010.02527.x.

Cooke GM, Landguth EL, and Beheregaray LB. 2014. Riverscape genetics identifies replicated ecological divergence across an Amazonian ecotone. Evolution. vol 68(7): 1947-1960. doi: https://doi.org/10.1111/evo.12410.

Damerau M, Matschiner M, Salzburger W, Hanel R. 2012. Comparative population genetics of seven notothenioid fish species reveals high levels of gene flow along ocean currents in the Southern Scotia Arc, Antarctica. Polar Biology. vol 35(7): 10731086. doi: https://doi.org/10.1007/s00300-0121155-x.

Davis CD, Epps CW, Flitcroft RL, Banks MA. 2018. Refining and defining riverscape genetics: how rivers influence population genetic structure. Wiley Interdisciplinary Reviews: Water. vol 5(2): 1-20. doi: https://doi.org/10.1002/wat2.1269.

Díaz-Ferguson E, Haney R, Wares J, Silliman B. 2010. Population genetics of a trochid gastropod broadens picture of Caribbean Sea connectivity. PLoS One. vol 5(9):1-8. doi: https://doi.org/10.1371/journal.pone.0012675.

Dorn A, Ng'oma E, Janko K, Reichwald K, Polačik M, Platzer M, Reichard M. 2011. Phylogeny, genetic variability and colour polymorphism of an emerging animal model: the short-lived annual Nothobranchius fishes from southern Mozambique. Molecular Phylogenetics and Evolution. vol 61(3): 739-749.

doi: https://doi.org/10.1016/j.ympev.2011.06.010.

Dung DT, Hop NT, Thaenkham U, Waikagul J. 2013. Genetic differences among Vietnamese Haplorchis taichui populations using the COI genetic marker. Journal of Helminthology. vol 87(1): 66-70. doi: https://doi.org/10.1017/S0022149X12000041.
Esa YB, Rahim KAA. 2013. Genetic structure and preliminary findings of cryptic diversity of the Malaysian mahseer (Tor Tambroides Valenciennes: Cyprinidae) inferred from mitochondrial DNA and microsatellite analyses. BioMed Research International. vol 2013: 1-15. doi: https://doi.org/10.1155/2013/170980.

Excoffier L, Lischer HEL. 2010. Arlequin suite Ver 3.5: a new series of programs to perform population genetics analyses under Linux and Windows. Molecular Ecology Resources. vol 10(3): 564-567. doi: https://doi.org/10.1111/j.17550998.2010.02847.x.

Hubert N, Meyer CP, Bruggemann HJ, Guérin F, Komeno RJL, Espiau B, Causse R, Williams JT, Planes S. 2012. Cryptic diversity in indo-pacific coral-reef fishes revealed by DNA-barcoding provides new support to the centre-of-overlap hypothesis. PLoS One. vol 7(3): 1-8. doi: https://doi.org/10.1371/journal.pone.0028987.

Jacoby D, Gollock M. 2014. Anguilla marmorata. The IUCN red list of threatened species 2014: E.T166189A45832585.

https://www.iucnredlist.org/. doi: https://doi.org/http://dx.doi.org/10.2305/IUCN.UK .2014-1.RLTS.T166189A45832585.en.

Jacoby D, Harrison IJ, Gollock M. 2014. Anguilla bicolor. The IUCN red list of threatened species 2014: E.T166894A67015710. https://www.iucnredlist.org/. doi: https://doi.org/http://dx.doi.org/10.2305/IUCN.UK .2014- 1.RLTS.T166894A67015710.en.

Fahmi MR. 2015. Short communication: Conservation genetic of tropical eel in Indonesian waters based on population genetic study. Prosiding Seminar Nasional Masyarakat Biodiversitas Indonesia. vol 1(1): 38-43. doi: https://doi.org/10.13057/psnmbi/m010106.

Fahmi MR, Hirnawati R. 2010. Keragaman ikan sidat tropis (Anguilla sp.) di perairan Sungai Cimandiri, Pelabuhan Ratu, Sukabumi. Prosiding Forum Inovasi Teknologi Akuakultur. vol 1(1): 1-8.

Froese R, Pauly D. 2019. World wide web electronic publication. www.fishbase.org. Assessed August 2020.

Hall T. 2011. BioEdit: an important software for molecular biology. GERF Bulletin of Biosciences. vol 2(1): 160-161. doi: https://doi.org/10.1017/S0317167100012865.

Hebert PDN, Cywinska A, Ball SL, DeWaard JR. 2003. Biological identifications through DNA barcodes. Proceedings of the Royal Society B: Biological Sciences. vol 270: 313-321. doi: https://doi.org/10.1098/rspb.2002.2218.

Hughes JM, Schmidt DJ, Finn DS. 2009. Genes in streams: using DNA to understand the movement of freshwater fauna and their riverine habitat. BioScience. vol 59(7): 573-583. doi: https://doi.org/10.1525/bio.2009.59.7.8. 
Kanno Y, Vokoun JC, Letcher BH. 2011. Fine-scale population structure and riverscape genetics of brook trout (Salvelinus fontinalis) distributed continuously along headwater channel networks. Molecular Ecology. vol 20(18): 3711-3729. doi: https://doi.org/10.1111/j.1365-294X.2011.05210.x.

Ko HL, Wang YT, Chiu TS, Lee MA, Leu MY, Chang KZ, Chen WY, Shao KT. 2013. Evaluating the accuracy of morphological identification of larval fishes by applying DNA barcoding. PLoS One. vol 8(1): 3-9. doi: https://doi.org/10.1371/journal.pone.0053451.

Kumar S, Stecher G, Li M, Knyaz C, Tamura K. 2018. MEGA X: Molecular evolutionary genetics analysis across computing platforms. Molecular Biology and Evolution. vol 35 (6): 1547-1549. doi: https://doi.org/10.1093/molbev/msy096.

Liu X, Cao Y, Xue T, Wu R, Zhou Y, Zhou C, Wu X. 2017. Genetic structure and diversity of Nodularia douglasiae (Bivalvia: Unionida) from the middle and lower Yangtze River drainage. PLoS One. vol 12(12): 1-23. doi: https://doi.org/10.1371/journal.pone.0189737.

Matarese AC, Spies IB, Busby MS, Orr JW. 2011. Early larvae of Zesticelus profundorum (Family Cottidae) identified using DNA barcoding. Ichthyological Research. vol 58(2): 170-174. doi: https://doi.org/10.1007/s10228-010-0198-7.

Minegishi Y, Gagnaire PA, Aoyama J, Bosc P, Feunteun E, Tsukamoto K, Berrebi P. 2012. Present and past genetic connectivity of the Indo-Pacific tropical eel Anguilla bicolor. Journal of Biogeography. vol 39(2): 408-420. doi: https://doi.org/10.1111/j.1365-2699.2011.02603.x.

Muchlisin ZA, Batubara AS, Fadli N, Muhammadar AA, Utami AI, Farhana N, Siti-Azizah MN. 2017. Assessing the species composition of tropical eels (Anguillidae) in Aceh Waters, Indonesia, with DNA barcoding gene Cox1. F1000Research. vol 6: $1-10$.

doi: https://dx.doi.org/10.12688\%2Ff1000research.107 15.1 .

Nei M. 1987. Molecular evolutionary genetics. New York: Columbia University Press.

Nuryanto A, Pramono H, Sastranegara MH. 2017a. Molecular identification of fish larvae from east plawangan of Segara Anakan, Cilacap, Central Java, Indonesia. Biosaintifika: Journal of Biology \& Biology Education. vol 9(1): 33-40. doi: https://doi.org/10.15294/biosaintifika.v9i1.9191.

Nuryanto A, Qonita NH, Pramono H, Kusbiyanto K, Soedibja PHT. 2017b. Genetic Variation In Cytochrome B-Hinf1 And -Alu1 Gene Correlated To Body Size In Soang Gourami (Osphronemus Goramy Lacepede, 1801) From Single Spawning. Biosaintifika: Journal of Biology \& Biology Education. vol 9(2): 185-192. doi: https://doi.org/10.15294/biosaintifika.v9i2.9301.

Nuryanto A, Amalia G, Khairani D, Pramono H, Bhagawati D. 2018. Molecular Characterization Of
Four Giant Gourami Strains From Java And Sumatra. Biodiversitas. vol 19(2): 578-584. doi: https://doi.org/10.13057/biodiv/d190228.

Nuryanto A, Komalawati N, Sugiharto. 2019. Genetic diversity assessment of Hemibagrus nemurus from rivers in Java Island, Indonesia using COI gene. Biodiversitas. vol 20(9): 2707-2717. doi: https://doi.org/10.13057/biodiv/d200936.

Olsen JB, Crane PA, Flannery BG, Dunmall K, Templin WD, Wenburg JK. 2011. Comparative landscape genetic analysis of three Pacific salmon species from subarctic North America. Conservation Genetics. vol 12(1): 223-241. doi: https://doi.org/10.1007/s10592-010-0135-3.

Parmaksiz A, Eksi E. 2017. Genetic diversity of the cyprinid fish Capoeta trutta (Heckel, 1843) populations from Euphrates and Tigris Rivers in Turkey based on mtDNA COI sequences. Indian Journal of Fisheries. vol 64(1): 18-22. doi: https://doi.org/10.21077/ijf.2017.64.1.62396-03.

Pavesi L, de Matthaeis E, Tiedemann R, and Ketmaier V. 2011. Temporal population genetics and COI phylogeography of the sandhopper Macarorchestia remyi (Amphipoda: Talitridae). Zoological Studies. vol 50(2): 220-229.

Pegg GG, Sinclair B, Briskey L, Aspden WJ. 2006. MtDNA barcode identification of fish larvae in the southern Great Barrier Reef, Australia. Scientia Marina. vol 70(2): 7-12. doi: https://doi.org/10.3989/scimar.2006.70s27.

Pereira LHG, Hanner R, Foresti F, Oliveira C. 2013. Can DNA barcoding accurately discriminate megadiverse Neotropical freshwater fish fauna? BMC Genetics. vol 14: 1-14. doi: https://doi.org/10.1186/1471-2156-14-20.

Pike C, Crook V, Jacoby D, Gollock M. 2020. Anguilla bicolor (amended version of 2019 assessment). The IUCN red list of threatened species 2020: e.T166894A176494582. https://www.iucnredlist.org/. https://dx.doi.org/10.2305/IUCN.UK.20203.RLTS.T166894A176494582.en.

Rachmawati FN, Susilo U. 2011. Profil hormon dan kinerja reproduksi ikan sidat (Anguilla bicolor McClelland) yang tertangkap di perairan Segara Anakan Cilacap. Journal of Biota. vol 16(2): 221226. doi: https://doi.org/10.24002/biota.v16i2.103.

Ratnasingham S, Hebert PDN. 2013. A DNA-based registry for all animal species: the barcode index number (BIN) system. PLoS One. vol 8(8): 1-16. doi: https://doi.org/10.1371/journal.pone.0066213.

Rozas J, Ferrer-Mata A, Sanchez-DelBarrio JC, GuiraoRico S, Librado P, Ramos-Onsins SE, and SanchezGracia A. 2017. DnaSP 6: DNA sequence polymorphism analysis of large data sets. Molecular Biology and Evolution. vol 34(12): 3299-3302. https://doi.org/10.1093/molbev/msx248.

Sabando MC, Vila I, Peñaloza R, Véliz D. 2011. Contrasting population genetic structure of two 
widespread aquatic insects in the Chilean highslope rivers. Marine and Freshwater Research. vol 62(1): 1-10. doi: https://doi.org/10.1071/MF10105.

Sachithanandam V, Mohan PM, Muruganandam N, Chaitanya IK, Dhivya P, Baskaran R. 2012. DNA barcoding, phylogenetic study of Epinephelus spp. from Andaman Coastal Region, India. Indian Journal of Geo-Marine Sciences. vol 41(4): 203 211.

Song LM, Munian K, Rashid ZA, Bhassu S. 2013. Characterisation of Asian snakehead murrel Channa striata (Channidae) in Malaysia: an insight into molecular data and morphological approach. The Scientific World Journal. vol 2013: 1-17. doi: https://doi.org/10.1155/2013/917506.

Sugeha HY, Bataragoa NE, Wouthuyzen S. 2008. Inshore migration of the tropical Anguillid Glass Eels recruited in the estuary of Dumoga River (North Sulawesi, Indonesia). Prosiding Seminar Nasional lkan V. June 3, 2008. Bogor: Masyarakat Iktiologi Indonesia. ISBN 979-3688-89-0. hal 225237.

Sugeha HY. 2010. Recruitment mechanism of the tropical glass eels genus Anguilla in the Poso Estuary, Central Sulawesi Island, Indonesia. Jurnal Perikanan. vol XII(2): 86-100.

Sugeha HY, Arai T. 2010. Contrasting morphology, genetic, and recruitment season of Anguilla marmorata glass eels from northern, western, and central Sulawesi Island, Indonesia. Ilmu Kelautan. vol 1: 1-19.

Sugeha HY, Genisa MU. 2015. External and internal morphological characteristics of glass eels Anguilla bicolor bicolor from the Cibaliung River Estuary, Banten, Indonesia. Oseanologi dan Limnologi di Indonesia. vol 41 (1): 37-48.

Tanaka C, Shirotori F, Sato M, Ishikawa M, Yoshinaga T, Shinoda A, Aoyama J. 2014. Genetic identification method for two subspecies of the Indonesian short-finned eel, Anguilla bicolor, using an allelic discrimination technique. Zoological Studies. vol 53(1): 1-7. doi: https://doi.org/10.1186/s40555-014-0057-8.

Wouthuyzen S, Aoyama J, Sugeha HY, Miller MJ, Kuroki M, Minegishi Y, Suharti SR, Tsukamoto K. 2009. Seasonality of spawning by tropical anguillid eels around Sulawesi Island, Indonesia. Naturwissenschaften. vol 96(1): 153-158. doi: https://doi.org/10.1007/s00114-008-0457-X.

Yan RJ, Zhang GR, Guo XZ, Ji W, Chen KC, Zou GW, Wei KJ, and Gardner JPA. 2018. Genetic diversity and population structure of the northern snakehead (Channa argus Channidae: Teleostei) in Central China: implications for conservation and management. Conservation Genetics. vol 19(2): 467-480. doi: https://doi.org/10.1007/s10592-0171023-X.

Zhang GH, Yuan ZJ, Zhang CX, Yin KS, Tang MJ, Guo HW, Fu JY, Xiao Q. 2014. Detecting deep divergence in seventeen populations of tea geometrid (Ectropis obliqua Prout) in China by COI MtDNA and cross-breeding. PLoS One. vol 9(6): 19. doi: https://doi.org/10.1371/journal.pone.0099373. 